\title{
A Smart specialization strategy for sustainable development of regions
}

\author{
Georgi Manolov ${ }^{1}$, Dinara Orlova $^{2}$, Julia Khodkovskaya $^{3}$, Ekaterina $_{\text {Barkova }}{ }^{3}$, and Michail \\ Nazarov $^{4}$ \\ ${ }^{1}$ Higher School of Security and Economics, Bul. "Kuklensko Shosse" , 13, 4004 Plovdiv, Bulgaria \\ ${ }^{2}$ Financial University under the Government of Russian Federation, Leningradsky Prospekt \\ Str., 49, 125993 Moscow, Russia \\ ${ }^{3}$ Ufa State Petroleum Technical University, Kosmonavtov Str., 1, 450064 Ufa, Russia \\ ${ }^{4}$ Samara state university of economics, Sovetskoy Armii Str., 141, 443090 Samara Russia
}

\begin{abstract}
Changes in the global economy facilitated the creation of new strategies and models for socio-economic development of countries and areas. The transition to a digital technological level, the strengthened role of the civil society and the priority of national interests determine the necessity to search for tools to provide a sustainable and coordinated development of territories, creating a favorable economic, social and institutional environment and conditions for a well-balanced interaction of all participants on the market. One of the tools for highly effective transformations is social innovation, which has a huge socio-political transformative potential. The article presents the theoretical basis and the opportunities for practical implementation of the strategy for smart specialization of regions. It shows the application of helix models and social innovations in strengthening the socio-economic position of regions and increasing their competitiveness and sustainability.
\end{abstract}

\section{Introduction}

The stability of the regional economy, the sustainable economic growth, the effective management of budgetary risks and the protection of economic interests in regional budgets with the minimization of all threats arising during ventures make it possible to form monetary and currency funds and financial reserves in sufficient volume to fulfill the expenditure obligations of the budgets. The focus is solely on budget balancing limits, and sometimes even excludes the allocation of budgetary resources to finance projects in the field of research and development and to launch new socially significant products on the market that do not provide a quick compensation for the budgetary expenses.

Despite the social orientation at all levels of budgets in our country, the territorial economic stability remains one of the main goals of modern social policies. Therefore, the constituent entities of the Federation aim to save budget funds and to obtain a budget effect from the made investments, and (thus) give up social innovations that do not provide immediate results. The inadequacy of this approach towards ideas for improving the social welfare and the quality of life enhances contradictions between society and the state. Furthermore, the satisfaction of social needs requires the supply of goods and services with 
the qualities of environmental friendliness, safety, general accessibility for the consumers, etc., which determine public value.

The concepts, practical guides and management standards for sustainable development of the areas highlight the methods that can be used to assess the effectiveness of institutional, economic, social and environmental transformations in the region, and, moreover, to set forth long-term development goals for the region based on the priorities of national politics.

The emphasis on achieving the criterion "efficiency-sustainability" of a region's development allowed developing new constructive forms of interaction between government authorities and the business community. However, the implemented social projects often fail to recognize the modern societal demands for creating and promoting social innovations. In this regard, at a territorial level, regional authorities become the regulator without taking into account specific factors and conditions affecting the efficiency of managing a sustainable development in the given region. One way to balance out the interests of the Federation's entities, the business community and the civil society is to form a strategy for smart specialization of regions.

Having studied the best Russian and foreign practices of social policy implementation, the authors present a study in which they propose a mechanism for an interface between the interests of the Federation's entities, the business community and the civil society via helix models and social innovations in the sustainable development of regions.

\section{Materials and Methods}

Focusing on national values, national interests, reforming the system of social services and introducing social and environmental standards has brought to the forefront the issue of forming a sustainable development strategy of regions that meets the needs of modern society. There is no uniform understanding of the economic value of social policies in today's society. However, at a territorial level, universal approaches are generally used to assess the sustainability of the development. One of their principles is homogeneity of the compared objects (territories). In this regard, the applied system of assessment indicators is based on the homogeneity of the conditions: socio-economic, legal, environmental, etc. Nevertheless, as practice shows, it is necessary to take into account the specific individual characteristics of the regions.

Various methodological approaches are used to assess sustainable development of territories in international management. Thus, most widespread have become the international standard "System of environmental-economic accounting" of the UN Secretariat's Statistics Division, the Index of sustainable development, the genuine index of the World Bank, the Index of Sustainable Economic Welfare, the genuine progress indicator, the Human Development Index, the Environmental Sustainability Index and others.

The methodological basis of this article was provided by the work of leading Russian and foreign researchers, which describe the types (individualistic, populist and collectivist) and models of social policies (Hayek-Nozick, Roza, Habermas, ordoliberal Polanyi, Marx) [1]. add

The features of the concepts for sustainable development of countries and territories abroad were studied on the example of Scandinavian countries [2-4]. The nature of social practices in modern society was studied on the basis of classifications proposed by $\mathrm{J}$. Mulgan, S. Tucker, R. Ali, B. Sanders, K. Tanimoto, and others [5,6].

Analyzing the efficiency of the use of social innovations in the development of territories and countries and the potential of their practical use in the social network [7-9], and taking into account factors of motivation, creativity, social reflection, etc., the basic 
theories of social innovation were studied: S. Kuznets, G. Mensha, the concept of technological paradigm, the NBIC-Convergence phenomenon, etc., as well as models of the „triple helix", "quadruple helix" and "quintuple helix" in the innovative development of regions $[10,11]$.

The formation of strategies for the sustainable development of countries and regions and the development of key aspects of an effective socio-economic policy was based on modern Russian research and international experience $[12,13]$.

A research in the design features of the strategy for smart specialization of regions and in the role and participation of social technologies in the sustainable socio-economic development of regions was conducted with the aid of the methodological and practical set of standards and guidelines on social responsibility of the companies (ISO 26000, GRI, ISO 14000 and SA 8000). The main documents in the examination of the Russian practices in relations between the government and the business community were the Memorandum on Corporate Social Responsibility Principles, documents of the Social Charter of the Russian Business, and the Code of Business Ethics of the Chamber of Commerce \& Industry of the Russian Federation.

An analysis of the scientific approach and the applied research allowed to identify problems and controversial aspects in the management of sustainable regional development.

Applying the method of system analysis, the study used Rosstat's statistical data, information from analytical economic reviews and the results of research by rating agencies.

\section{Results and Discussion}

An analysis of the methodological guidelines and standards used to assess sustainability showed that the diversity of indicators and indices characterizes the economic, environmental and social condition of territories. Such focus of the methodology demonstrated the importance of the impact of the specified indicators on regional sustainability assessments. However, in most of the currently used methods, the priority in achieving balance and sustainability is determined by the efficiency of the application of financial and budgetary tools and by the efficiency of the formation and utilization of budgetary resources. Moreover, there is ambiguity in the assessment of efficient use of resources in a certain territory, since most methods apply a deterministic approach that does not take into account the impact of risk and uncertainties.

It should be noted that one of the key parameters ensuring self-development of the region at present is the efficient use of resources of a particular area. The industrial features of a region, the differentiation in socio-economic development, the level of investment and innovation activity, and the degree of digital transformation of methodologies remain underestimated. Therefore, such assessments can only be used as initial information for the creation of long-term socio-economic forecasts for regional development and the design of sustainable development strategies.

Achieving the main goal of regional development in accordance with the criterion of "efficiency-sustainability" is accompanied by the transformation of existing forms of constructive interaction between the authorities, the business community and the civil society, while their balanced interaction is facilitated by the convergence of institutional spheres. In this regard, the effective international practices of forming regional development strategies are of research interest: the precedence in the practice of strategic planning of territory development belongs to the helix models.

Currently are known the "triple helix", "the quadruple helix" the "quintuple helix".

The "triple helix", which has proved itself in the foreign practice of territorial socioeconomic development, is a strong environment for relations between the regional authorities, the business community and scientific circles. In this model, the role and 
significance of each entity is defined through participation in innovative transformations. However, the mission, the target indicators of economic activity and the methods to achieve social and economic benefits demonstrate significant contradictions between the participants in innovative transformation. Furthermore, the economic effects of the implementation of digital solutions in the business community have exacerbated the crisis in the social sphere and increased the divergent interests of the business community and regional authorities. Therefore, the "triple helix" model can only be used as an operational approach to stimulate innovation at the regional level. This is due to the fact that the "triplehelix" model is based on the existence of a "technological paradigm" in the areas that is created by the interaction and the exchange of know-how between the main actors.

A feature of the "triple helix" model is the recurring renewal of the technological paradigm in accordance with stages of the innovation process and change in the role of the entities. In particular, the creation of cooperation between the regional authorities and the business community requires the support of scientific communities to stimulate innovation. At an early stage in the development of the technological paradigm, the role of both the scientific community and the regional government decreases in favor of the business community. As the existing technological paradigm matures, the scientific communities and regional governments are again taking the lead, while offering new technological paradigms and laying the foundation for a new wave of innovation.

Foreign experts believe that the triple helix model is particularly effective for regions with a developed innovation industry and hybrid institutions, which are supported by the relevant regional authorities. In regions where the above conditions are not met, the triple helix model may be ineffective. This is particularly common for regions that demonstrate insignificant economic growth and a lack of innovation space due to the dominance of traditionally managed small and medium-sized enterprises, or where the benefits of application-orientated scientific communities are not being exploited. These features have been taken into account in the „quadruple helix“ model.

In the "quadruple helix" model the actors are the regional authorities, the business community, the scientific community and the civil society. In this model, scientific knowledge is assessed for its social sustainability and inclusivity, while taking into account the social impact. This model focuses on new discoveries and innovations (social innovations, eco-innovations) that improve the social well-being of society.

The "quadruple helix" model joints the social economy, the society and the environment with knowledge generation and innovation. The most important subject of the quadruple helix is an active civil society as a resource of scientific and practical knowledge, which determines the potential for creating the results of intellectual property in society (knowhow, inventions, etc.). Consequently, the "quadruple helix" model enhances the process of interaction between institutional forms through transfer of innovation, creation of integration structures and development of new regional markets [13].

The "quadruple helix" model traditionally distinguishes between the economic and political environment, the civil society and the educational environment:

- the political environment forms the direction in which the state/regions are currently moving, as well as laws, norms, rules - the political and legal assets;

- the economic environment consists of branches of economy, business units - the economic assets;

- the civil society - culture based on mass media unites two forms of assets: social assets and information assets.

- the educational environment is academic circles, universities, higher education systems, etc. - intellectual assets.

According to the "quadruple helix" model, the regional authorities, the business community and the scientific community support the civil society in socially-oriented 
activities. Thus, innovations in terms of products and services focused on meeting the needs of citizens (user-oriented innovations) ensure the socio-economic growth of the region and the transition from technical to social innovations.

The "quintuple helix" model focuses mainly on the socio-environmental component. As in the "quadruple helix" the drivers of regional development are innovations and knowledge, the reproduction of which ensures the socio-economic development of the regions. This model aims at forming a competitive resource-efficient region, where all communication relationships between the entities are highly effective.

The socio-environmental component of the "quintuple model" as a whole embodies the key objectives of the European socially oriented market economy, the values of which are "green" investments [14], a social conflict-free environment and a balance between market efficiency and social justice.

In general, the helix models are recommended for regions with a strong innovation industry and existing hybrid institutions, which are supported by the relevant regional authorities.

Sustainability analysis of Russia's regions over 2015-2019 revealed that less than half of the constituencies of the Federation belong to regions with a stable socio-economic position - regions with strong/weak growth (Moscow, St. Petersburg, the Khanty-Mansiysk Autonomous Okrug - Yugra, Moscow Oblast, Yamalo-Nenets Autonomous Okrug, Republic of Tatarstan, Zabaikalsky Krai, Sverdlovsk Oblast, etc.). Most of the regions are classified as unstable - regions with decreasing key indicators characterizing the socioeconomic position (Republic of Tyva, Chukotka Autonomous District, KarachayCherkessia Republic, Jewish Autonomous Region, Republic of Altai, Republic of North Ossetia - Alania, etc.). Thus, helix models that have been successfully applied in foreign practice require adaptation to Russian conditions. Nevertheless, when formulating recommendations for the application of helix models in strategic planning practices in Russian regions, legislative and legal requirements should be taken into account. Thus, the adopted concept for a long-term development of the Russian Federation "Strategy 2020" contains recommendations on regional strategies for innovative development, which would stimulate the design of innovations for socio-economic development, taking into account individual socio-economic, resource-based and other characteristics of the regions. In this regard, applying a horizontal organization of diversified control is a reasonable approach to smart regional specialization. It should be noted that the directions of regional development in the concept of long-term development of the Russian Federation largely resonate with the strategy "Europe 2020" [15]:

- "smart" economic growth (combining innovation and knowledge);

- sustainable economic growth (balanced development of the economic, environmental and social sphere);

- inclusive economic growth (enhancing integration processes in all spheres of human activity $=$.

The strategy of sustainable regional development based on the smart specialization of regions is a prerequisite for the creation of an open and socially-oriented innovation space in modern Russia.

An analysis of the practice of introducing "smart specialization" in the European Union and the USA indicates that when designing regional strategies one needs to take into account all the aspects of economic development, the availability of resource potential, the environmental characteristics, the scientific and innovation potential within the framework of specific areas of societal development. This is why regional strategies should be fully individualized. Therefore, the application of "smart specialization" in Russia should be based on the principle of forming a regional strategy, while taking into account competitive advantages and disadvantages, as well as the existing potential of a particular region. 
The principles of introducing "smart specialization" to form a territorially oriented innovation strategy were based on the analysis of sustainability/unsustainability of Russian regions - the strategy of intellectual specialization of regions:

- the first principle - the strategy of "smart specialization" should focus less on the artificial creation and development of perspective sectors of economy and business, and much more on the development of the established business infrastructure of the regions;

- the second principle is specialized diversification. The currently emerging priorities will not be maintained constantly, and after a few years should be replaced by new ones. In the strategy of "smart specialization" the priorities that have reached maturity are reviewed;

- the third principle is based on the theory of experimental learning and the development of the idea of self-knowledge. The innovative focus of a regional strategy should allow for experiments to discover what works and what does not in a particular context. To determine success, failures must also be noted;

- the fourth principle - "smart specialization" should be inclusive [15]. This means that inclusive intellectual specialization will give each sector the chance to participate in strategy development through a good project.

In accordance with the aforementioned principles, an algorithm for forming a strategy for smart specialization of regions has been developed.

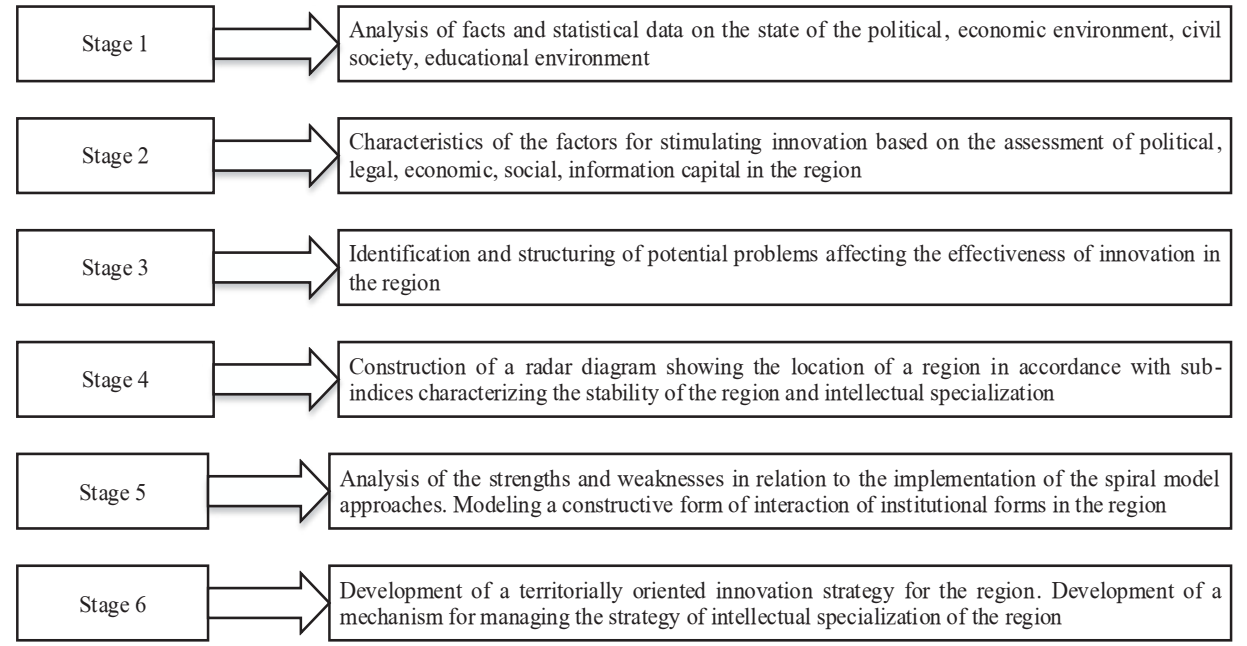

Fig. 1. Algorithm for forming a strategy of intellectual specialization of the region

Taking into account the carried out integration processes both at the regional and international levels, the digital development of the Russian economy provides a real opportunity to consider global social events when forming the strategy of intellectual specialization of the region. Based on the studied foreign practices and the proposed algorithm of forming the strategy of smart specialization of a region, it is necessary to recognize the effects of international cooperation when forming a strategy. Therefore, the key elements that determine the structure of communications at the regional level in this algorithm are the state, the business community, the scientific community, the civil society and the international organizations.

The role of international organizations as key partners in comprehensive socioeconomic cooperation is growing due to the development of global networks of communication and exchange, the growth in the number of transnational corporations, the creation of common electronic portals, etc. This allows the unification of physical, digital, social and other capital, and is manifested through: 
- participation in the process of developing national standards that meet global environmental requirements;

- development of the domestic law of international organizations;

- assistance in integration and technology transfer;

- involving intermediary organizations and partners in the innovation market (technology transfer centers, business innovation centers, development agencies, etc.) $[16,17]$

- encouraging investment activity in the region (grant support, investment loans, leasing programs, etc.);

- formation of joint enterprises ensuring inflow of new technologies, knowledge, etc., into the region;

- developing forms and methods of social cooperation, facilitating the exchange of best practices in the social sphere.

Building a constructive interaction between all participants during the implementation of the region's smart specialization strategy and the resulting organizational decisions should relate to the development of the social competence of the state, the business and the civil society and the progress in balancing the interests of all institutional forms.

\section{Conclusions}

The research conducted in this article allowed us draw the following conclusions:

1. The criterion of "efficiency - sustainability" is used in assessing the sustainability of regional development to define new forms of interaction between government, business and civil society as strategic partners. The results of the regional rankings serve as baseline data for structuring regional development problems, identifying potential growth areas and activating internal resources of institutional forms.

2. The unstructured, flexible and autonomous nature of social innovation makes it less related to the structural conditions and strategic assets of the territory. Social innovation is a driving force for developing cross-border cooperation and networking to stimulate the exchange of new ideas, competencies and know-how. Social innovation in modern economic conditions should be perceived as a form of establishing integration relationships, which enables a rapid response to technological innovations.

3. Helix models combine resources and expand regional capacities. They allow taking into account the dynamic nature of the social space and the importance of stimulating socially oriented innovations, which are present in all sectors of the economy and contribute to consensus among all participants in the socio-economic environment in the development of a regional development strategy.

4. When developing a smart specialization strategy for regions in order to improve economic development and competitiveness, it is necessary to use social indicators with both a quick and a long-lasting effect, such as public demand for social benefits, quality and environmental friendliness of publicly important goods and services, safety of social conditions in the region, etc.

The establishment of a common digital space throughout the entire territory of the Russian Federation [18] and the country's integration into the global information and communication system allow to create strategies for sustainable development of regions considering the results of global social events that affect the economic, political and social environment in the region. 


\section{References}

1. R. A. Svistun, Essences and main directions of state social policy in Russia, Book 1. (2017)

2. T. Brandsen, G. Ecchia, J. Eschweiler, L. Hulgård, R. Nogales, Co-creating a Social Innovation Research Agenda for Europe, Social Innovation Europe, EMES Network (2016)

3. J. Kaivo-oja, S. Vähäsantanen, A. Karppinen, T. Haukioja, Research Journal of Business Management, 15(1), 28 (2017)

4. Y.V. Khomenko, L.A. Khomenko, Economic Bulletin of Donbass, 4(38), (2014)

5. G. Mulgan, S. Tuckers, R. Ali, B. Sanders, Social innovation: what it is, why it matters and how it can be accelerate, London (2007)

6. K. Tanimoto, Int. J. Innovation and Regional Development, 4 (2012)

7. T. Brandsen, G. Ecchia, J. Eschweiler, L. Hulgård, R. Nogales, Co-creating a Social Innovation Research Agenda for Europe, Social Innovation Europe, EMES Network (2016)

8. J. Howaldt, C. Kaletka, A. Schröder, M. Zirngiebl. Atlas of Social Innovation - New Practices for a Better Future. Sozialforschungsstelle, TU Dortmund University: Dortmund (2018)

9. J. Howaldt, C. Kaletka, A. Schröder, M. Zirngiebl. Atlas of Social Innovation. A World of new Practices, 2 (2019)

10. E. Carayannis, E. Grigoroudis. Quadruple Innovation Helix and Smart Specialization: Knowledge Production and National Competitiveness. Foresight and STI Governance, 10(1) (2016)

11. E. G. Carayannis, D. F. J. Campbell, International Journal of Social Ecology and Sustainable Development, 1(1) (2010)

12. E. Holden, K. Linnerud, D. Banister, Sustainable Development, 25 (2016)

13. F.A. Huq, M. Stevenson, Implementing Socially Sustainable Practices in Challenging Institutional Contexts: Building Theory from Seven Developing Country Supplier Cases. J Bus Ethics, 161 (2020)

14. G. F. Tokareva, O. I. Shalina, E. E. Barkova, IOP Conference Series: Earth and Environmental Science C, 012138, (2018)

15. Carayannis E., Grigoroudis E., Foresight and STI Governance, 10(1) (2016)

16. M.E. Agwu, H.N. Onwuegbuzie, J Innov Entrep, 7, 12 (2018).

17. M. M. Malmström, J. Johansson, J Innov Entrep, 5, 4 (2016)

18. D. R. Orlova, Yu. V. Khodkovskaya, R. B. Sharafutdinov, Euroasian law Journal, 9 (124) (2018) 